\title{
Applying ABCDE and Assessment for Personal and Social Learning to Studying the Classics to Equip Students with the European Qualification Framework Competences Incrementally for Recovery from Covid 19
}

\author{
Alison Taysum \\ External Examiner University of Ulster, N. Ireland, UK \\ Daniela Canfarotta \\ Mihaela-Viorica Ruşitoru \\ Raquel Casado-Muñoz
}

Arto Kallioniemi

\begin{abstract}
The professional challenge of this paper is education systems do not have a road map to achieve the Target 4.7 of the Sustainable Development Goals (SDG) to ensure that all learners acquire the knowledge and skills needed to promote a culture of peace. The Covid 19 is causing fear about economic stability and individuals experience conflict physically, mentally emotionally, and spiritually. It is very important that policy makers support education systems, teacher training and teacher leadership empirical models to foster self-knowledge for good decision making. This will prepare citizens to optimise alignment of commercial interests with sustainable interests with a labour market replete of citizens with Competency Levels of the European Qualification Framework gained through life long learning situated in rich diverse cultural heritages. We apply A Blueprint for Character Development for Evolution with Assessment for Personal and Social Learning to the Classics curriculum and reveal applying $\mathrm{ABCDE}$ in five steps maps to the incremental Competences Levels 1 - 5 respectively of the European Qualifications Framework. Step A asks questions to establish what the problem is. Step B asks what solutions have or have not worked before. Step C asks how the problem is understood in context. Step D provides empirical, logical, ethical and innovative solutions to the problems emerging from the data. Step E establishes principles to inform good decision making that can be readily transferred to other domains. ABCDE with APSL applied to classics curriculums provides a road map to empowering young societal innovators for equity and renewal.
\end{abstract}

Keywords: ABCDE, Assessment, Personal and Social Learning, Classics, Students, European Qualification Framework Competences, Incrementally for Recovery, Covid 19

\section{Introduction}

The professional challenge this paper addresses is education systems need a road map to achieve Target 4.7 of the Sustainable Development Goals to: 'ensure that all learners acquire 
the knowledge and skills needed to promote sustainable development, including, among others, through education for sustainable development and sustainable lifestyles, human rights, gender equality, promotion of a culture of peace and non-violence, global citizenship and appreciation of cultural diversity and of culture's contribution to sustainable development'. The rich historical development of the Sustainable Development Goals can be tracked back to: a) The Paris Declaration (OECD, 2011) on Promoting citizenship and the common values of freedom, tolerance and openness to cultural diversity and intercultural understanding that is not i) articulated normatively in curriculum Intended Learning Outcomes (European Council, 2006); MUR 2007) and ii) not realised in practice in society amongst groups with different levels of interest and cultural, political and economic power. The political context is one where young people are leaving school without understanding how their own cultural identity and heritage aligns with local, national, regional, bloc and international contexts of diverse cultural identities and heritages, languages, traditions, and social relations in political and economic networks. This is exacerbated with the Covid 19 pandemic which is causing fear about economic stability, access to resources/goods and the production of these goods in a context of millions of people being furloughed. Around the world we are seeing an increase in Violence, Uncertainty, Chaos and Ambiguity (VUCA).

Dewey (1910) suggests the consequences of beliefs, acts, and goods the production of the goods, access to the goods and the prioritisation of those goods, or in other words the pragmatic consequential impact of beliefs on acts, or goods during a person's lived life may be great. This is particularly so during or post the Covid 19 pandemic. In a social contract, if these elements do not align with social justice, individuals will experience clashes that create conflict physically, mentally, emotionally, and spiritually. If individuals are in classes where they are not encouraged to challenge or ask questions they will not know how to articulate what the problem is, or suggest solutions to the problem, rather they just know there is a problem. Internal angst of the personal world that clashes with inequity in the social world can lead to mistrust, which can further damage a person's physical, mental emotional and spiritual health. This kind of damage reduces a person's quality of life and their productivity and undermines a social contract build on moral principles that assure an ethical framework. The impact on personal civic engagement in big society and the labour market is huge. People working 3 jobs in a 'gig' economy with zero hour contracts have no possibility of saving for a home, a family and paying into a pension pot and become homeless if there is no work. These people have been very vulnerable to Covid 19 in the pandemic which was taking place at the time of us writing this article. A healthy aging strategy is not going to be sufficient as a strategy for retired people with no pension and who are not fit enough to work. Policy makers need to trust people with an education that will engender synthesis of: i) traditional knowledge with new technologies and ii) faith with reason. Policy makers need to policise education systems that provide citizens with the thinking tools to gain Self-Knowledge For SelfGovernance.

This deskbased policy analysis (Taysum and Iqbal, 2012) allows identification of key aspects of a classics curriculum that can be explored using a model 'A Blueprint for Character Development for Evolution (ABCDE)' with 'Assessment for Personal and Social Learning (APSL)'. The paper aims to demonstrate the usefulness of ABDE with APSL to provide a road map for developing critical judgment and the skills required to participate with Open Access Science with and for Society (SwafS). Participation with SwafS aims to develop communities' grassroots up solutions to align commercial interests and sustainable development with 
Higher Education as a hub for new partnerships with lifelong learning education systems. ABCDE with APSL applied to the classics makes this possible. This has consequences for providing a road map to teacher training to achieve the Sustainable Development Goals (UN, 2016). For future research, this model can be applied to other school subjects because it enables the Competences of the European Qualifications Framework to be mapped to school curriculums and the pedagogies and text books that are moblised to meet the Intended Learning Outcomes that are addressed in the examination questions.

Our position in the paper is that Applying a deliberative thinking framework to classics curriculums will develop the competences of ET2020 mapped to the Competency and Qualifications Framework which will Empower Young Societal Innovators for Equity and Renewal so that they can advocate for a secure social contract that amplifies equity, peace and prosperity. To test this hypothesis, we ask: how and in what ways can applying a deliberative framework $\mathrm{ABCDE}$ to the study of the Classics engender synthesis of traditional knowledge with new technologies and faith with reason to gain the competences of ET2020 by addressing the four strategic objectives and SDG Target 4.7.

\section{A Blueprint for Character Development for Evolution (ABCDE).}

Alienation allows exploration of challenges such as issues of the distribution of justice and power and goods and their means of production with the competence of asking questions (Stage A). They can explore the knowledge from classics knowledge bases that reveal themes and patterns of different civilizations in different ages at Stage B. The competence to conduct a review of the best that has been thought and said in an excavation of the Classical text, removes the citizen from the personal (the small) and allows them to think about intentions and acts of people in different societies (the big). By thinking in 'the big' citizens have the chance to discover and piece together the different kinds of knowledge in the knowledge bases; pathos, logos and ethos (Taysum, 2017). i) Pathos is evidence that is convincing or otherwise in terms of the substance of the speech and the character of the orator. ii) Logos is the regressive abstraction of ideas from the world prior to human laws mediated through human language and human's naming of objects and the division of labour and the tools/instruments. In an a-priori approach to knowledge humans can wrestle with utopian reimaginings and iii) ethos (ethical framework open to continuous moral inquiry, Pring, 2016). From the classics that are mythical, divine, lyrical, novelistic, comedic, tragic legalistic, satirical, medical historiographical, biographical, and philosophical, coupled with logical deduction and different ethical approaches to the networks between the people and their means of communication (the social media), the economy/driven by the industry metamorphosing into the digital age, Universities and governance systems (Ruşitoru, Kallioniemi, and Taysum, in press). They can develop methods for exploring the classics by site visits and visits to museums at Stage C. They can develop hypotheses for how intentions and acts create the kinds of conditions for prosecution of war, or peace. They can test hypotheses on casestudies from other ages in the classics, or renaissance, or the industrial age or modern times drawing on the exciting approaches of the Open Access grassroots up databases of Horizon 2020 'Science With and For Society' for example, at stage D. Young people can then identify if there are any principles that emerge from the hypotheses that help them understand the sustainable development goals (UN 2016) at Stage E. Table 1 presents A Blueprint for Character Development for Evolution (Taysum, 2019, p.76). 
Table 1. A Blueprint for Character Development for Evolution.

\section{Education Policy as a Roadmap for Achieving the SDGs}

\begin{tabular}{|c|c|c|c|c|c|}
\hline $\begin{array}{l}\text { Stage of Character } \\
\text { Development }\end{array}$ & Why? & $\begin{array}{l}\text { Transition from } \\
\text { Immaturity to } \\
\text { Maturity }\end{array}$ & $\begin{array}{l}\text { Impact on } \\
\text { Mental } \\
\text { Health }\end{array}$ & \begin{tabular}{|l|} 
Participation \\
in \\
Constructing \\
Social \\
Contract
\end{tabular} & $\begin{array}{l}\text { Likely \% of } \\
\text { Population to } \\
\text { Turn Out to } \\
\text { Vote }\end{array}$ \\
\hline A1. Obeys rules driven by fear & Senses fear of punishment & $\begin{array}{l}\text { Continues to fear } \\
\text { institutions in } \\
\text { behaviourist fight } \\
\text { of flight mode }\end{array}$ & $\begin{array}{l}\text { Poor } \\
\text { mental } \\
\text { health }\end{array}$ & None & Low \\
\hline $\begin{array}{l}\text { A2. Obeys rules driven by } \\
\text { getting even }\end{array}$ & $\begin{array}{l}\text { Senses fear and seeks } \\
\text { revenge if they are } \\
\text { wronged }\end{array}$ & $\begin{array}{l}\text { Continues to fear } \\
\text { institutions and } \\
\text { seek revenge for } \\
\text { wrongs done - } \\
\text { may be high } \\
\text { vigilance }\end{array}$ & $\begin{array}{l}\text { Poor } \\
\text { mental } \\
\text { health }\end{array}$ & None & Low \\
\hline $\begin{array}{l}\text { B. Obeys rules underpinned by } \\
\text { beliefs }\end{array}$ & $\begin{array}{l}\text { Believes in doing things } \\
\text { right but does not know } \\
\text { why in practice }\end{array}$ & $\begin{array}{l}\text { Confused which is } \\
\text { linked to } \\
\text { ambiguity which } \\
\text { can lead to } \\
\text { perpetuating } \\
\text { VUCA }\end{array}$ & $\begin{array}{l}\text { Poor } \\
\text { mental } \\
\text { health }\end{array}$ & Low & $\begin{array}{l}\text { Low - } \\
\text { medium }\end{array}$ \\
\hline $\begin{array}{l}\text { C. Obeys rules and chooses to do } \\
\text { duty within the law - with } \\
\text { methods and theories to help } \\
\text { predict consequence of acts with } \\
\text { missing information }\end{array}$ & $\begin{array}{l}\text { Developed methods to } \\
\text { find out how others have } \\
\text { done the right thing or } \\
\text { not with good application } \\
\text { of concepts in practice } \\
\text { for a good social contract } \\
\text { and embedded economy. }\end{array}$ & $\begin{array}{l}\text { Potential for } \\
\text { enlightenment and } \\
\text { human evolution }\end{array}$ & $\begin{array}{l}\text { Potential } \\
\text { for good } \\
\text { mental } \\
\text { health }\end{array}$ & High & High \\
\hline $\begin{array}{l}\text { D. Obeys rules and chooses to do } \\
\text { duty within the law and develops } \\
\text { hypotheses to test for proof of } \\
\text { concept to inform future good } \\
\text { decision making. }\end{array}$ & $\begin{array}{l}\text { Developed hypotheses to } \\
\text { do the right thing with } \\
\text { good application of } \\
\text { concepts for a good social } \\
\text { contract and embedded } \\
\text { economy }\end{array}$ & $\begin{array}{l}\text { Potential for } \\
\text { enlightenment and } \\
\text { human evolution }\end{array}$ & $\begin{array}{l}\text { Potential } \\
\text { for good } \\
\text { mental } \\
\text { health }\end{array}$ & High & High \\
\hline $\begin{array}{l}\text { E. Obeys rules and connects } \\
\text { duties with rights systematic } \\
\text { moral inquiry into the ethical } \\
\text { rules and leadership of } \\
\text { institutions }\end{array}$ & $\begin{array}{l}\text { Has arrived at and is } \\
\text { guided by universal } \\
\text { ethical principles applied } \\
\text { to the social life that have } \\
\text { stood the test of } \\
\text { Assessment for Personal } \\
\text { and Social moral inquiry }\end{array}$ & $\begin{array}{l}\text { Enlightened } \\
\text { human in } \\
\text { becoming } \\
\text { contributing to } \\
\text { human evolution }\end{array}$ & Good & High & High \\
\hline
\end{tabular}

Fig. 4.1. Taysum (BERA, 2018c) Five Stages of Character

Development to Build Trust in the Social Contract Applying ABCDE.

Young people can therefore apply ABCDE to develop theories of change for peace and prosperity in new partnerships that are kind to people and planet to meet SDG Target 4.7 and the four strategic objectives of ET2020. Thinking in the big and arriving at principles can then be applied to the personal again to lead to discerning decision making/good judgements and decisions. This allows citizens to re-imagine how and why particular interests were furthered for harmonious ecologies that benefit the self and others (human evolution) or at the 
disharmonious ecologies at great cost to the self and most others (human exploitation). Seeking prime principles and applying their understanding might be called arriving at 'ethical standards' for human behaviour. These standards as an overarching framework such as the 'Declaration of Human Rights', empower citizens and young people to A) can ask what goods, and instruments of production were of value and by who,what the literature about the classics reveal about patterns of human behaviour, C) to learn which methods are most appropriate to collect data to describe and understand which virtues are most treasured, or despised, and what the drivers for intentions and acts were, D) to develop hypotheses to test for proof of concept such as what will happen to the world if it is driven by fear and why, or if it evolves with love and why, or a hybrid of these and why, and to E) develop principles to be applied in the personal (the small) and the social (the big).

\section{John Dewey: learning from the ancestors to achieve the SDGs}

Dewey suggests (1909) one of the best ways to learn from history is to see historical periods far from the current life of the citizens here and now. The possibility of reflecting on what happened in those times and of studying the predicates to beliefs and behaviours throughout particular eras, their consequences, and imagined alternative outcomes, offers citizens and young people the chance to: a) get a sense of how and why certain interests have been promoted at the expense of others; b) identify the beliefs and virtues at the time that prioritised particular goods and their means of production (Adler, 1941); c) to develop methods to collect data and analyse these; d) to make hypotheses and test them to critically evaluate which virtues were most appreciated and which they imagine might be most appreciated and if this is applied equitably to all or if different groups enjoyed different levels of education leading to different pathways of participation in a social contract written by and for an elite group; e) identify principles that will underpin theories of change.

\section{Learning from the Classics}

Tragedians of the classics actualized the mythical events that were chosen in the contemporary social and political perspective and sought the intimate ethical and religious motivations that justified their dramatization. What is more, attention to the ethical theme, in Greek tragedy, took the form of the debate between the characters (Rossi \& Nicolai, 2015). In this way critical thinking of citizens of the polis developed as they examined the different perspectives and different kinds of knowledge of the characters of the play.

Democracy is not made only by the human rules and institutions, but also by political culture, social cohesion, personal and collective responsibility. Tension can be produced between two aspects. First between the integrating function of society, exercised by human political power as a vector for legal construction of political community and its governance. This is a horizon of legislative compatibility of pluralism and the recomposition of interests of different social groups in consensual strategies of administrative management. Second the normativity (and rationality, perhaps even the logic of what 'should' be in an ideal world) peculiar to one or more communities of axiological nature (philosophical nature of value) in political or religious terms. Understanding these tensions and applying knowledge to understanding of democracy in today's world is in fact one of the major topics (Bartolomei, 2018). This is indeed the crux of the professional challenge this paper addresses; The Paris Declaration (OECD, 2011) on Promoting citizenship and the common values of freedom, tolerance and openness to cultural diversity and intercultural understanding is not i) articulated normatively in curriculum Intended Learning Outcomes (ILOs) and ii) not realised in practice in society amongst groups with different levels of interest and cultural, political and economic power. 
The Greeks, more even than the Romans, value how to question received opinion and authority. Stated in Chapter 28 of Encheiridion, Epictetus' handbook compiled by one of his students Arrian in the 2nd century:

If someone turned your body over to just any person who happened to meet you, you would be angry. But are you not ashamed that you turn over your own faculty of judgement to whoever happens along, so that if he abuses you it is upset and confused?

This short quotation invites the reader to consider how and in what ways humans have clear boundaries for the physical body and what a human(s) can and cannot lawfully do to the body of another. Yet education policy does not include ILOs to develop the faculty of judgement.

Edith Hall states in her Gaisford 2015 Lecture: Pearls before Swine? The Past \& Future of Greek; Oxford University:

Greek Texts need to be available to every trainee citizen at every school in our land...the ancient Greeks pioneered many of the genres and tone of voice in which we still express ourselves, lyric, novelistic tragic comic satiric legal medical historiographical, biographic, philosophical. The 50+ major authors writing in Greek made scientific discoveries, experienced historical crises, and debated philosophical quandaries of direct relevance to our own...Sometimes they got it right the idea that art needs to enlighten as well as delight and sometimes they got it wrong; slavery. (The Greeks) developed skills which would advantage every modern citizen of the 21st century; the science of rhetoric or effective communication, the formula for making decisions in a way that maximises the chances of the decision being a good one. The Artistotelian notion that crimes of omission can have worse effects than crimes of commission, the accountability of those who govern us, the idea that learning from the past can help humans avoid repeating mistakes, an inclusive approach to other ethnic groups' Gods and above all the discipline of Utopian thinking; constructive imagining of what a fairer, better society and environment might look like than any hitherto built by man. Above all from the humans' very first appearance at Hesiod contending with the gods of Mecone the Greeks were politicised 'for when Gods and moral humans were engaged in a dispute making a distinction between each other at Mecone'.

Perhaps the greatest indicator of who has power and who does not, is the right and the duty, within a social contract, to be able to ask questions. The competence of asking questions therefore needs to be at the heart of problem solving following ABCDE. At stage A students can meet the competency to clearly articulate a professional challenge and ask good questions that address the professional challenge. At stage B meet the competency to fully and freely participate in Open Access knowledge bases of Science with and for Society. At stage $\mathrm{C}$ meet the competency to design and implement methods in collaboration with the other/society to gather baseline data and impact data to critically evaluate the professional challenge by addressing the questions. At stage D meet the competency to develop hypotheses from the impact data as theories of change that testing for proof of concept. At stage E meet the competency to extrapolate prime moral principles that guide the moral inquiry into the efficiency and effectiveness of the social contract to propel new partnerships that are kind to people and planet that sustainably propel entrepreneurial economies for peace and prosperity for all (United Nations, 2016).

Classics offers good opportunities to meet these competences starting with knowing how to ask good questions that address a sharply focused challenge/real-life problem from the classics. Students can then operationalise their transferable skills and make sense of the 
problem from classics in the $21^{\text {st }}$ Century using ABCDE. The transferable learning opportunities for the $21^{\text {st }}$ century world is that students' hypotheses of the conditions that led to the problem and the acts that caused the problem in the classics, can be synthesised with $21^{\text {st }}$ century new technologies to develop theories of change. Drawing on Professor Hall's lecture there is not one area of knowledge today, that the Greeks did not consider including lyric, novelistic, tragic, comic, satiric, legal, medical, historiographical, biographic, philosophical. The nature of humans persists in terms of psychologies, philosophies and ethics of trust in a social contract. In other words, the citizen is susceptible to the same kinds of virtues and temptations that press upon the character, but each age brings new technologies.

In the study of the classics, the shaping of a character through encounters on life's journey reveal interactions with others' power and desire to control or free others. This control is revealed through education policy and the first question is: does education policy prioritise ILOs to ask questions? If it does not, curriculums are creating compliant citizens who do not ask questions, which is a barrier to working together in the recovery from Covid 19.

Aristotle sought ways to develop the capacity for discernment between the truth and received opinion. He sought critical analysis of intentions and acts (and where more importantly would these be found than in the strategies/manifestos and their realisation by elected states people) by considering their ethical dimensions (ethos), the strength of empirical evidence found in the character of the witness/interlocuter (cathos) and logic or normative (logos) (Aristotle, 1926; Taysum, 2017). Socrates believed the unexamined life being, in his view, not worth living. For these reasons Hobbes thought that studying the classics, reading Greek and Roman authors, should be banned by any self-respecting tyrant. In Leviathan he argues that they foment under the slogan of liberty, instilling in people a habit 'of favouring uproars, lawlessly controlling the actions of their sovereigns, and then controlling those controllers' (Hall, 2015).

One of the most famous tragedies that deepens the connection between civic duties and personal responsibility, through use of critical thought, is Sophocles' Antigone. The tragedy stages events following the tragedy of Aeschylus "Seven against Thebes". Brothers Eteocle and Polinice killed each other in a duel. Creon, king of Thebes, forbids burial of Polinice as a traitor. Antigone, their sister, does not obey the law of Creon and is able to covertly bury Polynices. Discovered, she defends herself by saying that she has followed not human laws but divine laws. Creon will condemn her to death, but, before sentence is executed, Antigone will commit suicide. Fate of pain will also accompany Creon, because his son who is in love with Antigone kills himself at the loss and Creon's wife also commits suicide at the loss of her son (Rossi \& Nicolai, 2015).

As Cacciari (2018) a well-known Italian philosopher, teaches in his editing of Sofocle's work Antigone he identifies there is a big difference between what is "Just", that is governed by Dike (justice), and what is Nomos (Greek laws). Dike refers to a cosmic order, or universal principles that connects with Kant's prime principle (Kant, 1785). This may be aligned to what in Jurisprudence (the philosophy of law) is the "natural law". Within the law of the land, where the dominant Greeks might conquer another group and take their land, a "Right" person may not accept a law of the city if they believe that it does not recognize the natural order of things, or Dike, or justice as a Universal principle. Antigone's act to bury her brother followed Dike which to her was more important and just than Nomos. Nomos here is Greek law regarding i) the appropriation of territory, ii) the division of the territory and iii) the ordering of a 
territory. So, with a strategy of colonisation or the implementation of Nomos, the impact will include extra entitlement for the dominant elite groups who write the Nomos. Nomos is explicitly articulated in a state strategy/manifesto for colonisation that the citizens elect. The question students might ask is Should those who write the Nomos.

do so to perpetuate their own extra entitlement and elite status? or

to optimise the wellbeing, prosperity and happiness of all citizens to deliver on their professional goal of public service with and for society in a social contract for the good of all citizens? and

who can independently regulate the Nomos? and

how can corruption at all levels of society be exchanged for noble intensions and acts? and

what kind of Intended Learning Outcomes in lifelong learning curriculums and education policy will empower all citizens to gain the competences of ABCDE to be able to express a rational goodwill fully explicit and fully known to that rational being, and they can make the moral laws and abide by the moral laws that all others would be happy to also arrive at if they had to make them as rational beings (Taysum, 2019, p. 257)?

The great ancient philosophers, Plato and Aristotle sought a golden mean on the continuum with Dike (justice) at one end and Nomos (distribution of land, goods and their means of production) at the other by adding a third construct. The third construct is "Agathòn" or 'good', philosophically and linguistically where logic can be found in the accurate representation of the perfect order only discoverable through regressive abstraction to the first forms (Saran, and Neisser, 2004) which a- priori pre-date sin.

The contrast between Dike and Nomos can be resolved by thinking of a city in which all men must constantly turn their conscience to Aghatòn, that is, to Good. On the other hand, for Aristotle the third term is "Isos", the equal. There is Dike (justice) if Nomos (political divisions of a territory as ownership between citizens) is in isos (in equilibrium or a state of equity

where each individual is honoured and respected with and for the dignity of all human life that does no harm to the self or the other. In other words, the ' $\mathrm{I}$ ' wants the good with and for the self and with and for the other.

Justice is the logos but it is not possible for humans to understand this logos or perfect Universal law because there has been so much confusion and errors since the beginning of time. Utopian thought, as Professor Hall advises above, gives us a chance to glimpse into what might be a-prior knowledge as we re-imagine, as first forms, what human life might have been in the absence of fear. Indeed living with peace and prosperity in a social contract, following the logic of a-priori law, might empower citizens to live a good life however they imagine that good life to be. ILOs will need to provide immature citizens with the narrative capital realised with access to language and tools to manage the language such as the competency to ask questions, leadership that is moral and assures the moral inquiry into the ethical laws and their logic. that affords such access and the logic of the laws that frame the social contract.

Cicero (2013) was a Roman statesman and became Consul in 63 BC with enormous influence on the Latin language until the 19th Century when the classics were referred to being in his style or not. Cicero believed divine law underlies universal principles regardless of religious beliefs. Cicero believed this to be the foundation on which government should be built. Cicero followed the Greek philosopher Aristotle and earlier Stoic teachers in upholding the idea of natural law. 
Students studying the classics and Cicero could apply their understandings of Dike, Nomos, and Isos to this era and other eras allowing them to meet the Intended Learning Outcome. Students can access and critically analyse and reflect, having the potential to apply learning strategies to critique whether the Dike, Nomos, and Isos were truly universally good, or if there was a flaw in their implementation. An Intended Learning Outcome for this might be: students can collect evidence that they can test for characteristics of 'fake news' because they can draw on a range of methods to establish the quality dimensions of their findings to optimise confidence in the warrants for the claims made (Taysum, 2019, p.13).

Meeting these ILOs allows students to bring doubts and conflicts out into the open to be appraised to meet the Intended Learning Outcome: has a clear understanding of the role of societal institutions in different eras in creating equity, where they can be discussed and judged (Taysum, 2019, p.13). Such synthesis of different kinds of knowledge in different kinds of societies with different kinds of economies, goods, and their means of production allows students to meet the Intended Learning outcome: can recognise privilege and i) how this may be perpetuated based on class, race, gender, disability, or any of the protected characteristics of the Equalities and Human Rights Commission (2010) UK Equality Act and ii) how this leads to community cohesion and peace (Taysum, 2019, p.13). Thus, students can get a sense of and an understanding of how to develop more inclusive interests by studying the tragedean classics (Visnovsky \& Zolcer, 2016). This enables them to study the classics with ABCDE and APSL to devlop understandings of how solid democracy might be achieved, and its connection with every citizen being educated including the vulnerable, for example those with Special Educational Needs and Disabilities (SEND) being protected.

Studying the classics with ABCDE with APSL prove to be precious because they ignite students' interests in civic engagement at a personal and social level. As students engage with the Greek tragedies, they develop the competency to ask themselves questions about what they do, how they do, and why they do. Inquiring minds underpin human evolution. In the 21st century, with social media, it is possible to visit all places in the world virtually and young people's sense of adventure and discovery is very different to young people previously going on 'gap year voyages of discovery'. Yet perhaps the next frontier, and the most exciting and important voyage of discovery for young people to go on, is the discovery of who they are, and who they want to be, and to ask of their education, teachers, leaders and policy makers, 'how is the education offer available to me going to help me realise my ambitions and how can I map my progress on this, the most exciting journey of my life?' Thus, education policy can offer a road map for citizens to examine their own lives by using ABCDE with APSL to study the classics. The classics explores STEM and Science, Humanities, and Arts to Propel Economies (SHAPE). Therefore they can do this using the classics applying ABCDE and APSL to understand how lessons learned from the tragedies can empower young people, the leaders of the future, to not repeat the mistakes of the past with scope to do this with other disciplines.

What is more, learning from texts requires reflection on how far one has mastered the material. If learners use such metacognitive processes, they may decide whether to engage in deeper learning activities or not. To understand learning contents appropriately, learners have to work on the lexical to gain insight into the underlying semantic meaning (Jucks \& Paus, 2012). Such intellectual operations also brings into play the affective and motivational aspects of the student: if there 
is a reflection on the meaning of the whole learning process, including learning the language, the student can grow in self- knowledge and self-government (Bernacki et al., 2015; Efklides, 2011).

For example, already in the Iliad Ettore the brave hero gets angry with Paris because in him he sees the cause of the Trojan war and curses his birth and his marriage with Elena. Paris replies by saying:

"Do not reproach me for the gracious gifts of the golden Aphrodite; you must not despise, you know, the glorious gifts of heaven. It is heaven that assigns them to us: we have no way of choosing" (Iliad 3, 65-67).

Can young people explore what friendship is, and rights and duties, and what a good partnership/marriage is built on? Can examining this Greek Tragedy and Epic enable students to meet the competences of being able to present hypotheses of, let's say, good relationships, and then test these for proof of concept with other Greek tragedies, or tragedies of today? How might this prepare young people with right expectations for friendships, and relationships, and how might this help them develop narrative capital to have good and lasting friendships?

Another example is that of Achilles when he proclaims himself responsible for the death of Patroclus. According to the ancients, he was guilty of the most serious of crimes: he betrayed friendship. Despite this, in the book 19, when the two opponents are reconciled in the interests of the common homeland, Agamemnon says:

"I am not guilty. Zeus, Destiny, the Erinni who walks in the fog, they, during the assembly, put me suddenly in the soul a mad error (Ate), that day when, on my own initiative, I stripped Achilles of his part of the booty. What could I have done? Only the sky brings everything to fulfilment "(Iliad, 19, 86-90).

The fatal ascertainment that commits crimes of which men are not responsible is the Error (Ate), the genius of evil that will often appear in Greek tragedies. The Error is personified:

"The Error is the eldest son of Zeus: he, the cursed, causes all beings to wander. One day he made Zeus himself err, which is said to be above the gods, as he is above men" (Iliad, 19, 9194).

So, Error may confuse humans' faculty of judgement who hand their faculty of judgement over to Error without discernment as identified in Encheiridion by Epictetus above as arguably worse than handing over your body to another to abuse. Even, in Homer the humans judge that Zeus made a mistake without the a-priori logic and reasoning of Zeus' intention for the acts. Applying $\mathrm{ABCDE}$ in an education system in the Classics curriculum empowers humans to critically evaluate their intentions and acts operationalising the competencies at each Stage of ABCDE. Stage E is reached incrementally, having progressed through the previous stages ABCDE during an academic career that map to the Competences and Levels of the European Qualifications Framework (European Commission, 2020) see Table 2 The incremental ABCDE mapped to Incremental Levels and their Competences of European Qualifications Framework (European Commission, 2020).

Table 2. The incremental ABCDE mapped to Incremental Levels and their Competences of European Qualifications Framework (European Commission, 2020). 


\begin{tabular}{|c|c|}
\hline Competency from $\mathrm{ABCDE}$ and validated through APSL & Competency European Qualifications Framework (EQF) \\
\hline A.Competency to ask good questions. & $\begin{array}{l}\text { Level } 1 \text { of the EQF Competences 'Basic skills required to } \\
\text { carry out simple tasks. }\end{array}$ \\
\hline $\begin{array}{l}\text { B.Competency to interrogate the best that has been } \\
\text { thought and said about the constructs of the questions. }\end{array}$ & $\begin{array}{l}\text { Level } 2 \text { of the EQF Competences 'Basic cognitive and } \\
\text { practical skills required to use relevant information in } \\
\text { order to carry out tasks and to solve routine problems } \\
\text { using simple rules and tools' }\end{array}$ \\
\hline $\begin{array}{l}\text { C.Competency to design and implement methods that are } \\
\text { robust with high quality dimensions that yield baseline } \\
\text { data and impact data }\end{array}$ & $\begin{array}{l}\text { Level } 3 \text { of the EQF Competences 'A range of cognitive } \\
\text { and practical skills required to accomplish tasks and } \\
\text { solve problems by selecting and applying basic methods, } \\
\text { tools, materials and information'. }\end{array}$ \\
\hline $\begin{array}{l}\text { D.Competency to develop hypotheses from data that can } \\
\text { be tested for proof of concept }\end{array}$ & $\begin{array}{l}\text { Level } 4 \text { of the EQF Competences 'A range of cognitive } \\
\text { and practical skills required to generate solutions to } \\
\text { specific problems in a field of work or study'. }\end{array}$ \\
\hline $\begin{array}{l}\text { E.Competency to exprapolate prime principles from } \\
\text { hypotheses with proof of concept. }\end{array}$ & $\begin{array}{l}\text { Level } 5 \text { of the EQF Competences 'A comprehensive } \\
\text { range of cognitive and practical skills required to develop } \\
\text { creative solutions to abstract problems'. }\end{array}$ \\
\hline $\begin{array}{l}\text { Apply ABCDE in the Quadruple Helix to achieve ET2020 } \\
\text { four Strategic objectives and SDG } 4.7 \text { which Empowers } \\
\text { Young Societal Innovators for Equity and Renewal } \\
\text { (EYSIER) to achieve all SDGs. }\end{array}$ & $\begin{array}{l}\text { Level } 6 \text { of the EQF Competences 'Advanced skills, } \\
\text { demonstrating mastery and innovation, required to solve } \\
\text { complex and unpredictable problems in a specialised field } \\
\text { of work or study'. }\end{array}$ \\
\hline $\begin{array}{l}\text { Teach ABCDE and develop leadership to implementat of } \\
\text { ABCDE with APSL to EYSIER }\end{array}$ & $\begin{array}{l}\text { Level } 7 \text { of the EQF Competences 'Specialised problem- } \\
\text { solving skills required in research and/or innovation in } \\
\text { order to develop new knowledge ad procedures and to } \\
\text { integrate knowledge from different fields. }\end{array}$ \\
\hline $\begin{array}{l}\text { Teach the leaders to implement ABCDE with APSL to } \\
\text { EYSIER }\end{array}$ & $\begin{array}{l}\text { Level } 8 \text { of the EQF Competences 'The most advanced } \\
\text { and specialised skills and techniques, including synthesis } \\
\text { and evaluation, required to solve critical problems in } \\
\text { research and/or innovation and to extend and redefine } \\
\text { existing knowledge or professional practice'. }\end{array}$ \\
\hline
\end{tabular}

\section{Classics curriculums in Schools}

In light of ET2020 objectives and Competency and Qualifications Framework recent educational reforms, teachers must evaluate students not only from the point of view of contents (summative assessment), but also of the competences they develop (formative assessment), building a bridge between information and formation. There is a wide debate about different conceptions of competence (Bicocca-Gino, 2017; Compagno, 2015; Di Pietro, 2013; Riva, 2017; Vidal Ledo et al., 2016, ET2020). Table 2 reveals the competences from the EQF (2020) framework mapped to Taysum's (2019) ABCDE through APSL. A) ask good questions about their learning, B) receive feedback from their teachers that provides them with scientific knowledge that they can compare and contrast with their current personal and implicit knowledge, C) develop methods to identify the gap between what they achieved in the assessment, what they needed to achieve and what they need to do to bridge their gap in the knowledge to get a higher grade (a higher grade validates their deeper learning and ability to apply their understanding). Crucially they are then given time with the formative feedback that contains more questions about what the student has achieved, what they need to achieve to get a higher mark that validates learning has occurred at a deeper level, D) Revise their assessment that applies their feedback and tests for proof of concept that their learning has 
empowered them to resubmit their draft and get a higher mark that validates deeper learning and E) identify

the prime principles of applying Assessment for Personal and Social Learning that allows them to transfer their competency to self-assess and thus develop their faculty of judgement that empowers them to recognise and avoid confusion and error. These stages of Assessment for Personal and Social Learning are identified in Table 3 'Assessment for Personal and Social Learning taking a Deweyan Perspective' (Taysum, 2019, 58).

Table 3. 'Assessment for Personal and Social Learning taking a Deweyan Perspective' (Taysum, 2019, 58).

\section{Education Policy as a Roadmap for Achieving the SDGs}

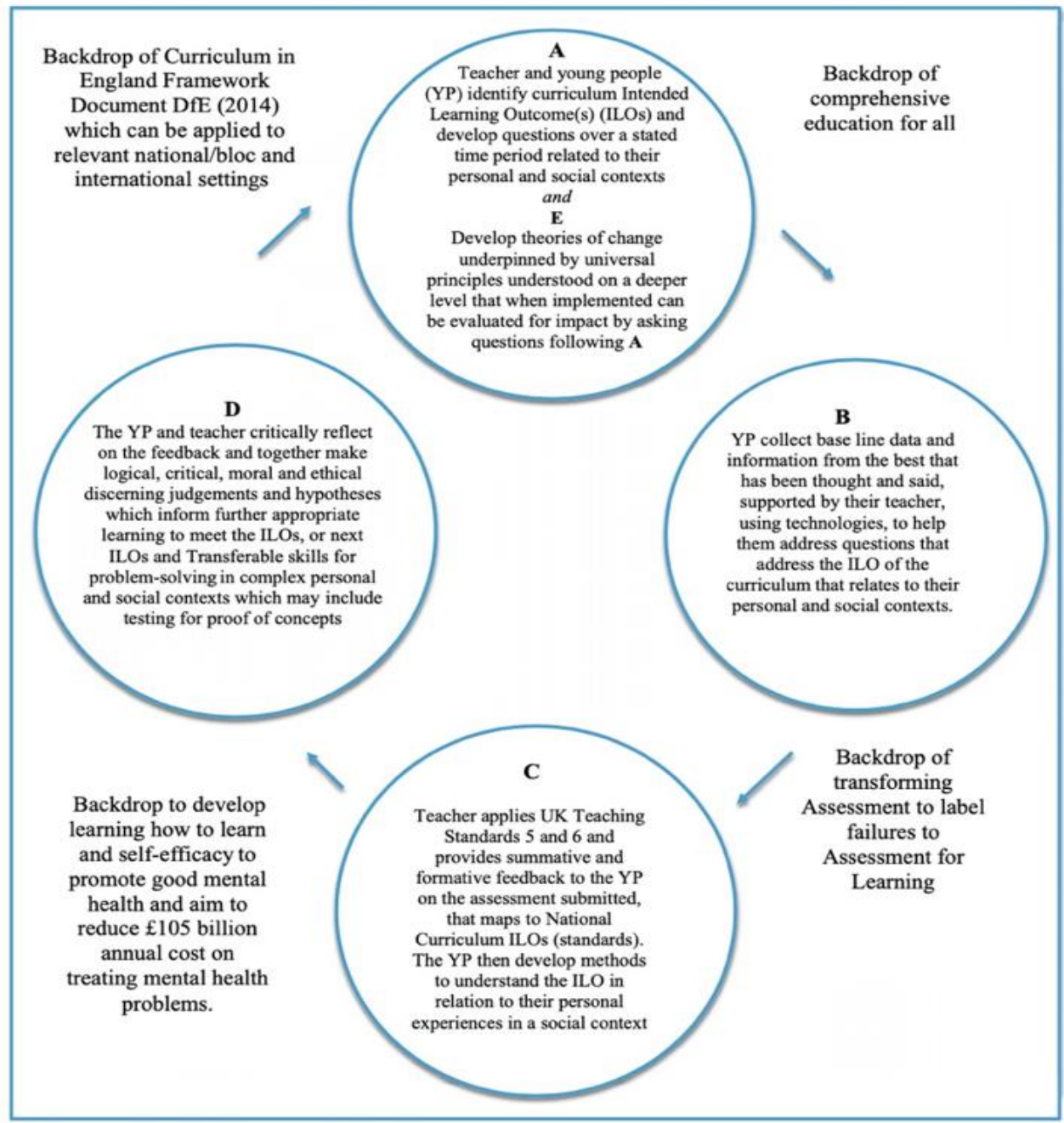

Fig. 3.1. A Framework for Assessment for Personal and Social Learning Taking a Deweyen Perspective. ${ }^{4,5}$ 
Our paper presents approaches for Assessment for Personal and Social Learning (APSL) to Validate key competences of ET2020 with a good faculty for judgement in a perspective of lifelong learning approach. Such good judgement can be applied successfully as a prime principle in the quadruple helix to propel personal and social development for a sustainable

cultural, economic, ecological and political social contract in relationship with the other for peace and prosperity meeting the SDG Target 4.7. Such examination using ABCDE with APSL Empowers Young Societal Innovators for Equity and Renewal (EYSIER) to understand what kinds of theories of change effected peace and prosperity for all in the classics and informs the development of theories of change in society for equity and renewal today. We acknowledge Shakespeare, found in English literature curriculums, drew on Greek epic tragedies. Shakespeare does not explore myths that allows transcendence and disciplined of Utopian thinking and the constructive imagining of what a fairer, better society and environment might look like than any hitherto built by man (Hall, 2015). This kind of development of good faculty for judgement is found in the classics curriculum.

A four year international study produced groundwork cases from England, Guyana, India, Kazakstan, Palestine, Nigeria, Northern Ireland, Republic of Ireland, Russia, United States all seeking to align with the competences of the ET2020 four strategic objectives (Taysum et al, 2020; Arar and Taysum, 2020). The groundwork cases found community members were not evaluating their learning or critically reflecting for themselves. Rather students gave their faculty of judgement to the teacher and teacher leaders as hierarchical figures, who gave their faculty of judgement to the hierarchical policy. Thus, the hierarchical figure was controlling participation in school and/or college processes and practices of learning. In the groundwork case studies initial intervention strategies moved from hierarchical summative assessment/decision making of learning to a distinctive mark of distributed leadership using whole school inquiry with time to reflect on formative feedback which led inter-cultural reflexive change. The change facilitated knowledge exchange, mobilisation, and dissemination activities that Empowered staff and young people to become Societal Innovators for Equity and Renewal which improved student outcomes between - 17\% and 27\%. From these ground work case studies Taysum identified there was a gap in the knowledge for an incremental framework for personal and social learning that would empower A Blueprint for Character Development for human Evolution (ABCDE) and develop the competences incrementally from Level 1 - Level 8 in a journey of lifelong learning. This proposal of ABCDE was presented in Education Policy as a Road to Achieve the Sustainable Development Goals (Taysum, 2019). This provided collaborators and potential funders with a structured handbook to understand the paradigm shift more clearly. This paper has addressed the gap and presents Table 4:

Table 4. Relationship between Taysum's ABCDE and EQF Competences mapped to a scheme of work from Classics curriculum and the European Recommendation of 2006 currently used in Italy, incremental progress impact and mapped to Competences from European Qualifications Framework (ET, 2020) 


\begin{tabular}{|c|c|c|c|c|}
\hline Action & $\begin{array}{l}\text { Classics Curriculum } \\
\text { Contents mapped to the } \\
\text { traditional } \\
\text { Recommendation of 2006, } \\
\text { Decree No. } 139 \text { of } 2007\end{array}$ & Impact of Progress & Measure of Impact of Progress & $\begin{array}{l}\text { Competences } \\
\text { from European } \\
\text { Qualifications } \\
\text { Framework } \\
\text { (EQF) } \\
\text { (European } \\
\text { Commission, } \\
\text { 2020) }\end{array}$ \\
\hline $\begin{array}{l}\text { Stage A } \\
\text { Competency to } \\
\text { define a problem } \\
\text { develop } \\
\text { objectives to } \\
\text { deliver a new } \\
\text { solution to an old } \\
\text { problem, and ask } \\
\text { good questions to } \\
\text { address the } \\
\text { objectives and } \\
\text { professional } \\
\text { challenge. Good } \\
\text { questions reveal } \\
\text { half the answer. }\end{array}$ & 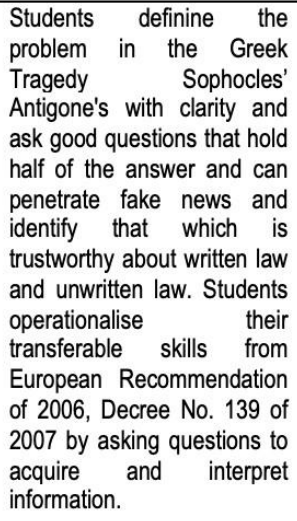 & $\begin{array}{l}\text { Students are able to define } \\
\text { problems with clarity and } \\
\text { ask good questions. This } \\
\text { change is a first step to } \\
\text { recognising fake news, } \\
\text { and trustworthy }\end{array}$ & $\begin{array}{l}\text { Students demonstrate nuanced } \\
\text { robust and discerning } \\
\text { constructive critique of different } \\
\text { world views using questions } \\
\text { that enable them to compare } \\
\text { the Classics to different time } \\
\text { periods and } 21^{\text {st }} \text { Century using } \\
\text { bottom up Open Access } \\
\text { Science with and For Society } \\
\text { knowledge bases verified with } \\
\text { Personal and Social } \\
\text { Assessment for Learning } \\
\text { (Taysum, 2019). }\end{array}$ & $\begin{array}{l}\text { Level } 1 \text { of the } \\
\text { EQF } \\
\text { Competences } \\
\text { 'Basic skills } \\
\text { required to } \\
\text { carry out simple } \\
\text { tasks. }\end{array}$ \\
\hline $\begin{array}{l}\text { Stage B } \\
\text { Competency to } \\
\text { interrogate the } \\
\text { best that has } \\
\text { been thought and } \\
\text { said about the } \\
\text { constructs of the } \\
\text { questions, the } \\
\text { objectives, and } \\
\text { the professional } \\
\text { challenge }\end{array}$ & $\begin{array}{l}\text { Students explore the lexicon } \\
\text { and the narrative of the text } \\
\text { of Antigone to generate } \\
\text { evidence informed, logical } \\
\text { and ethical understandings } \\
\text { compared and contrasted } \\
\text { with the best that has been } \\
\text { thought and said throughout } \\
\text { time, making good use of } \\
\text { Open Access 'Science With } \\
\text { and For Society' SwafS } \\
\text { bottom up knowledge bases } \\
\text { that helps them understand } \\
\text { themselves personally and } \\
\text { socially in terms of seeking } \\
\text { strategies that have worked } \\
\text { from the best that has been } \\
\text { thought and said ethically, } \\
\text { logically, and empirically } \\
\text { (evidence informed) }\end{array}$ & $\begin{array}{l}\text { Students will know which } \\
\text { method to choose; how to } \\
\text { collect data and mobilise it } \\
\text { to co-create evidence } \\
\text { informed, logical and } \\
\text { ethical impact strategies } \\
\text { that are culturally relevant } \\
\text { and beneficial to them } \\
\text { personally and socially. } \\
\text { Students build } \\
\text { interdependent and } \\
\text { interconnected } \\
\text { inclusionary partnerships } \\
\text { and communities of } \\
\text { practice for the seeking of } \\
\text { successful impact } \\
\text { strategies from the bottom } \\
\text { up interactions with the } \\
\text { SwafS knowledge base } \\
\text { (Horizon, 2020). This } \\
\text { develops cultural } \\
\text { alignment for equity which } \\
\text { correlates with developing } \\
\text { psychologies, philosophies } \\
\text { and ethics of trust. }\end{array}$ & $\begin{array}{l}\text { Students demonstrate nuanced } \\
\text { robust and discerning } \\
\text { constructive critique of different } \\
\text { world views verified by } \\
\text { tolerance for others and } \\
\text { harmonious relationships in the } \\
\text { classroom (teachers can } \\
\text { implement questionnaire from } \\
\text { Student Participation for } \\
\text { Empowerment to measure } \\
\text { impact of progress (Taysum } \\
\text { and Collins Ayanlaja, 2020)). }\end{array}$ & $\begin{array}{l}\text { Level } 2 \text { of the } \\
\text { EQF } \\
\text { Competences } \\
\text { 'Basic cognitive } \\
\text { and practical } \\
\text { skills required } \\
\text { to use relevant } \\
\text { information in } \\
\text { order to carry } \\
\text { out tasks and to } \\
\text { solve routine } \\
\text { problems using } \\
\text { simple rules } \\
\text { and tools' }\end{array}$ \\
\hline
\end{tabular}




\begin{tabular}{|c|c|c|c|c|}
\hline \begin{tabular}{|c|} 
Stage $C$. \\
Competency to \\
design and \\
implement methods \\
that are robustwith \\
high quality \\
dimensions that yield \\
baseline data and \\
impact data
\end{tabular} & \begin{tabular}{|} 
Students operationalisetheir \\
transferable skillsfrom European \\
Recommendation of \\
2006,Decree No. 139 of 2007 \\
and communicate and \\
collaborate with each other, \\
solve the problems found in \\
Antigone, they design methods \\
for acquiring and interpreting \\
information and operationalise \\
these including using new \\
technologies of a digital age \\
that engender participation in \\
Open Access bottom up \\
Science with and for Society \\
knowledge bases (Horizon \\
2020).
\end{tabular} & $\begin{array}{c}\text { Students will know which } \\
\text { method to choose; how to } \\
\text { collect data and mobilise it to } \\
\text { co-create evidence } \\
\text { informed, bgical and ethical } \\
\text { impact strategies that are } \\
\text { culturally relevant and } \\
\text { beneficial to them personally } \\
\text { and socially. }\end{array}$ & \begin{tabular}{|} 
Students demonstrate they can \\
choose methods to collect data \\
and mobiliseittoco-create \\
evidence informed (empirical) \\
logicalandethical impact \\
strategies that are culturally \\
relevent to them personally and \\
socially (teachers can implement \\
questionnaire from Student \\
Participationfor Empowerment to \\
measure impact of progress \\
(Taysum and Collins Ayanlaja, \\
2020) and map students \\
methods for exploring and \\
testing constructs from the \\
literature review to address \\
questions, deliver objectives and \\
solve problems mapped to the \\
Classics curriculum intended \\
Learning Outcomes.
\end{tabular} & \begin{tabular}{|} 
Level3of the EQF \\
Competences 'A \\
range of \\
cognitive and \\
practical skills \\
required to \\
accomplish \\
tasks and solve \\
problems by \\
selecting and \\
applying basic \\
methods, tools, \\
materials and \\
information' . \\
\end{tabular} \\
\hline $\begin{array}{l}\text { Stage D Competency } \\
\text { to develop } \\
\text { hypotheses from data } \\
\text { thatcan be tested for } \\
\text { proof of concept }\end{array}$ & $\begin{array}{l}\text { Students can plan solutions by } \\
\text { developing hypotheses that } \\
\text { they cantestfor proof of } \\
\text { concept and they can transfer } \\
\text { this competence to their every } \\
\text { day lives. Inthis waytheydonot } \\
\text { repeatwhat another does, } \\
\text { rather they execute a strategy } \\
\text { that they know works because } \\
\text { they have personally testeditin } \\
\text { thesocial world, orthatthey } \\
\text { believe is highly probableto } \\
\text { beeffectiveandarewillingto } \\
\text { execute the strategy to establish } \\
\text { proof of concept. Students } \\
\text { operationalisetheir transferable } \\
\text { skillsfrom European } \\
\text { Recommendation of } 2006 \text {, } \\
\text { Decree No.139of } 2007 \\
\text { learning howto learn withina } \\
\text { social contract, and } \\
\text { understanding how to seek } \\
\text { mitigation. }\end{array}$ & $\begin{array}{l}\text { Students'hypotheses are } \\
\text { verified by indicators of } \\
\text { progress with targets for an } \\
\text { evolving post-racial } \\
\text { community and evolving } \\
\text { gender relationships that the } \\
\text { students setfor themselves } \\
\text { and regulate } \\
\text { benchmarked to ABCDE. Their } \\
\text { learning communities are } \\
\text { characterised by tolerance } \\
\text { and understanding for those of } \\
\text { different faiths and none,race, } \\
\text { ethnicity, and they identify } \\
\text { next steps interms oftheir } \\
\text { learning how to learn that is } \\
\text { beneficialtothem personally } \\
\text { and socially. }\end{array}$ & $\begin{array}{l}\text { Students will have benchmarked } \\
\text { clear and transparent ways to } \\
\text { resolve conflict in a supportive } \\
\text { climate having explored this inthe } \\
\text { tragedy of Antigone that does not } \\
\text { disempower community members } \\
\text { to make them fearful and more } \\
\text { compliantwith confusing systems. } \\
\text { Any unresolved conflict Is reported } \\
\text { totheSeniorLeader ofthe } \\
\text { Education Governance System } \\
\text { who investigates and reports to the } \\
\text { Goveming Body and Parents' } \\
\text { Teachers'Association who } \\
\text { escalates to authorities if the } \\
\text { conflictis notresolved. } \\
\text { Operationalising metacognitive } \\
\text { reflection about the process } \\
\text { students become more focused } \\
\text { and avoid distractions and errors. }\end{array}$ & $\begin{array}{l}\text { Level4 ofthe EQF } \\
\text { Competences 'A } \\
\text { range of } \\
\text { cognitive and } \\
\text { practical skills } \\
\text { required to } \\
\text { generate solutions } \\
\text { to specific } \\
\text { problems ina field } \\
\text { ofwork or study'. }\end{array}$ \\
\hline
\end{tabular}




\begin{tabular}{|c|c|c|c|c|}
\hline \begin{tabular}{|c|} 
Stage E Competency \\
to extrapolate prime \\
principles from \\
hypotheses with proof \\
of concept from which \\
they can build \\
psychologies, \\
philosophies and \\
ethics of trust in bottom \\
up Swats Knowledge \\
Bases engendered by \\
studying the classics.
\end{tabular} & \begin{tabular}{|c|} 
Students can confirm or not, \\
prime principlesfrom the tragedy \\
Antigone and operationalse their \\
transferabe skills from European \\
Recommendation of 2006, \\
DecreeNo. 139of \\
2007 by acting autonomously and \\
responsily within a social contract. \\
They understand how to seek \\
mitigationwhen exercising their \\
rights and dongtheirduty ina \\
social contractandareableto \\
expressarationalgoodwill fully \\
exp citandfully known tothat \\
rationalbeing, and they can \\
make the moral lawsandabide \\
bythemoral lawsthatallothers \\
would behappy to alsoarrive atif \\
they had to make them as rational \\
beings'(Taysum, 2019, p.257).
\end{tabular} & \begin{tabular}{|c|} 
Students are able to effectively \\
extrapolate moral principles \\
from their studies of Antigone \\
and actautonomously and \\
responsblywithinasocial \\
contract mapped to Stage \\
EoABCDE.
\end{tabular} & $\begin{array}{l}\text { Students recognize principles of } \\
\text { behaviorandasconsumers of } \\
\text { bottomup OASwats knowledge } \\
\text { bases (Horizon 2020)areable to } \\
\text { parscientific excellence with social } \\
\text { awareness and responsibility. Thi } \\
\text { raises the aawareness of what to do } \\
\text { to to builda narrative capital to } \\
\text { engage with science careers, } \\
\text { gender equality,publc } \\
\text { engagement, science education, } \\
\text { open access/open data, } \\
\text { governance and ethics, the } \\
\text { precautionary principle,science } \\
\text { communication. Thisं verified by } \\
\text { learningcommuntieswith calm } \\
\text { climates that empower marginalised } \\
\text { groups with scientificknowledge } \\
\text { and dispositions for scientific } \\
\text { deberation to navigate turbulence } \\
\text { andbuid self regulation of reactions } \\
\text { to injusticesuch as bullying } \\
\text { (teachers can implement } \\
\text { questionnaire from Student } \\
\text { Participation for Empowerment to } \\
\text { measure impactofprogress } \\
\text { (Taysum and Collins } \\
\text { nunanon annou }\end{array}$ & \begin{tabular}{|c|} 
Level5of the EQF \\
Competences 'A \\
comprehensive \\
range of cognitive \\
and \\
practical skills \\
required to develop \\
creative solutions \\
to abstract \\
problems'.
\end{tabular} \\
\hline \begin{tabular}{|c|} 
F. Competency to \\
apply ABCDE in the \\
Quadruple Helixto \\
achieve ET2020 four \\
Strategic objectives \\
and SDG4.7which \\
Empowers Young \\
Societal hnovatorsfOf \\
Equityand Renewal \\
(EYSIER)to achieve all \\
SDGs.
\end{tabular} & $\begin{array}{l}\text { Lifelong learners can transfer the } \\
\text { competences Level } 1 \text {-5 from } \\
\text { addressing classics curriculum } \\
\text { htended Learning Outcomes to } \\
\text { addressing the strategic } \\
\text { objectives and targets of the } \\
\text { SDGs inthe quadrupe helix. }\end{array}$ & \begin{tabular}{|} 
hdividuals engage with the \\
abour market Of Higher \\
Education inthe quadrupt \\
helixwith advances skills that \\
demonstrate mastery and \\
nnovationn solving the complex \\
problemsby addressing the \\
questions that deliver the \\
objectives ofthetargetofeach \\
SDG toaddresstheproblem \\
dentified bytheSDG.
\end{tabular} & $\begin{array}{l}\text { Sub-groupsinthequadruple helix } \\
\text { usebaseineandimpact data } \\
\text { collected using the Monitoring } \\
\text { System of Responsible Research } \\
\text { and hnovation (MoRRI) to } \\
\text { benchmarkprogressagainst Key } \\
\text { Performance IndicatOfS of SDG } \\
\text { participatory open access Science } \\
\text { with and f Of Society (SwafS) } \\
\text { grassroots up Databases. } \\
\text { Progresses mainstreamedby } \\
\text { Professional Educators and } \\
\text { Administrators Committeesfor } \\
\text { Empowerment (Taysum, Rưoru } \\
\text { and Kallioriemi 2020l. }\end{array}$ & $\begin{array}{c}\text { Level } 6 \text { of the } \\
\text { EQF } \\
\text { Competences } \\
\text { 'Advanced skills, } \\
\text { demonstrating } \\
\text { mastery and } \\
\text { innovation, } \\
\text { Required to solve } \\
\text { complex and } \\
\text { unpredictable } \\
\text { problems in a } \\
\text { speciazed field of } \\
\text { work or study'. }\end{array}$ \\
\hline $\begin{array}{c}\text { G.Competencyto train } \\
\text { teachers and teacher } \\
\text { eaders to impement } \\
\text { ABCDE and develop } \\
\text { eadership to build } \\
\text { capacity } \\
\text { with policy makers in } \\
\text { the quadruple helix to } \\
\text { mainstream ABCDE } \\
\text { with APSL to EYSIER }\end{array}$ & $\begin{array}{c}\text { hstructors can train and educate } \\
\text { teachers and teacher eaders to } \\
\text { develop the competences } 1-6 \text { in } \\
\text { the classics curriculum }\end{array}$ & \begin{tabular}{|c|} 
hstructors benchmark \\
teachers' and teacher eaders' \\
reports of students' progress \\
against Classics Scheme of \\
Work Key Performance \\
hdicators.
\end{tabular} & $\begin{array}{l}\text { hstructors benchmark } 100 \% \\
\text { success rate of students meeting } \\
\text { their htended } \\
\text { Learning Outcomes of Classics } \\
\text { curriculum }\end{array}$ & $\begin{array}{l}\text { Level } 7 \text { of the } \\
\text { EQF } \\
\text { Competences } \\
\text { 'Specialised } \\
\text { problem-solving } \\
\text { skills requiredin } \\
\text { research and/or } \\
\text { innovation in } \\
\text { Ofdertodevebp nev } \\
\text { knowledge } \\
\text { andprocedures } \\
\text { andtointegrate } \\
\text { knowledge from } \\
\text { dferentfields. }\end{array}$ \\
\hline
\end{tabular}




\begin{tabular}{|c|c|c|c|c|}
\hline $\begin{array}{l}\text { H. Competency to } \\
\text { teach the leaders } \\
\text { to implement } \\
\text { ABCDE with } \\
\text { APSL to EYSIER }\end{array}$ & $\begin{array}{l}\text { Instructors can train and } \\
\text { educate the instructors of } \\
\text { those training and educating } \\
\text { teachers and teacher } \\
\text { leaders to develop the } \\
\text { competences } 1-6 \text { in the } \\
\text { classics curriculum }\end{array}$ & $\begin{array}{l}\text { Instructors benchmark the } \\
\text { teachers' and teacher } \\
\text { leaders' reports of their } \\
\text { successful training and } \\
\text { educating of teachers and } \\
\text { teacher leaders' reports of } \\
\text { students' progress against } \\
\text { Classics Scheme of Work } \\
\text { Key Performance } \\
\text { Indicators. }\end{array}$ & $\begin{array}{l}\text { Instructors benchmark } 100 \% \\
\text { success rate of their trainee } \\
\text { teachers and teacher leaders' } \\
\text { reports of students' meeting } \\
\text { their Intended Learning } \\
\text { Outcomes of Classics } \\
\text { curriculum }\end{array}$ & $\begin{array}{l}\text { Level } 8 \text { of the } \\
\text { EQF } \\
\text { Competences } \\
\text { 'The most } \\
\text { advanced and } \\
\text { specialised } \\
\text { skills and } \\
\text { techniques, } \\
\text { including } \\
\text { synthesis and } \\
\text { evaluation, } \\
\text { required to } \\
\text { solve critical } \\
\text { problems in } \\
\text { research and/or } \\
\text { innovation and } \\
\text { to extend and } \\
\text { redefine } \\
\text { existing } \\
\text { knowledge or } \\
\text { professional } \\
\text { practice'. }\end{array}$ \\
\hline
\end{tabular}

Taysum A., Ayanlaja C.C. (2020) Educational Success for Black Children in the Public School System:Parent Participation and Community Empowerment. In: Papa R. (eds) Handbook on Promoting Social Justice in Education. Online: Springer.

The authors are part of a large consortium seeking funding to test this model for proof of concept.

\section{Conclusion}

The hypothesis has been tested and reveals applying a deliberative framework ABCDE with APSL to the study of the Classics engenders synthesis of traditional knowledge with new technologies and faith with reason to gain the competences of ET2020 by addressing the four strategic objectives and SDG Target 4.7. This provides a road map to achieve Target 4.7 of the Sustainable Development Goals. This is possible when synthesising personal and implicit knowledge with the classics logical, empirical and ethical societal/curriculum content knowledge that spans Science Technology, Engineering, Maths, Arts and Humanities and all faiths and none (Hall, 2015). At Stage A) students and teachers ask questions that map back to the Classics curriculum's ILOs. At stage B) students synthesise personal implicit knowledge with societal disciplinary/curriculum traditional knowledge with new digitised technologies drawing on grassroots up Science with and for Society knowledge bases to produce their assessments for marking/validation against the competency framework. Here students meet Intended learning Outcomes of the classics curriculum by synthesising personal and implicit knowledge with the classics' logical, empirical and ethical societal/curriculum content knowledge of Science Technology, Engineering, Maths, Arts and Humanities and all faiths and none (Hall, 2015). At stage C) students apply methods to explore their summative feedback of their assessment (their outcome mapped to the competency qualifications framework). This summative feedback from their teacher is accompanied by formative feedback that provokes more questions. Students spend time with this feedback and map it to the marking criteria of the competency qualifications framework's ILOs for their programme of study which validates their content knowledge, its application to the real world and their competences for doing this. Students then move to stage D) where they revise and resubmit 
their assessment to test proof of concept that they can meet the ILOs of their programme of study at a higher/highest grade validated against the competency qualifications framework. Students then move to Stage E) where they have become masters of approaches to their Personal and Social Learning, Assessment and Validation of key competences of ET2020 with a good faculty for judgement. Such good judgement can be applied successfully as a prime principle in the quadruple helix to propel personal, scalable and social development for a sustainable cultural, economic, ecological and political social contract in relationship with the other for peace and prosperity.

In the study of the classics, a type of authoritarian power often emerges (this is the case of Creon against Antigone), which imposes itself on the characters and does not allow a contradiction brought about by questions, or critique to exist. Questions are vital to establish understanding between different sub-groups of society and to explore alternative ways of knowing and being. Exploring alternative ways of knowing and being by questioning Open Access databases of Science with and for Society (SwafS) (Horizon, 2020) is possible with a tool kit that provides the competences required to make good decisions. Applying ABCDE with APSL provides the model for establishing a new social contract in the quadruple helix through bottom up participation with the SwafS databases when applied to the classics curriculum to describe and understand power. Citizens are able to explore issues of power in the identity construction of different groups of humans within commercial, cultural, political and ecological boundaries that limit and/or optimise human evolution. In the classics textbooks groups of humans in the quadruple helix with high levels of entitlement enjoy high levels of access to privilege and physical evolution, those with low levels of entitlement do not. This leads to tensions and even conflict between the different subgroups where marginalised subgroups attempt to establish equilibrium, or even usurp the elite by taking their economic material wealth. Thus the group who are dominant over time become the marginalised groups and so the pendulum of power within the quadruple helix perpetually swings back and forth (Taysum and Arar, 2018). Antigone breaks the material law to bury her brother to follow the divine law. This suggests that the material wealth of humans is not necessarily aligned to the spiritual wealth of humans. To establish equilibrium between these two dimensions requires the mind which may be defined as 'logical theoretical logos prudence', and the emotions which may be defined as 'empirical pathos courage' to arrive at a third transparent moral (ethical/ethos/just) dimension (Taysum, 2017). When the three dimensions; logos, pathos and ethos are aligned satisfactorily a new social contract can be created. The new social contract is only satisfactory if all members fully and explicitly understand it, it does no harm to the self or the other, and all sign up for it willingly (Kant, 1775). Developing these competences could support recovery from Covid 19 by replacing fear with the competences to know how to question the things and people that cause fear. This could contribute to addressing the question; 'what does it mean to be 'more human', to develop those distinctively human qualities (competences) - indeed, to grow as persons (Pring, 2016).

\section{References}

[1] Adler, M. (1941). A dialectic of morals: Towards the foundations of political philosophy. Notre Dame, IN: University of Notre Dame

[2] Arar, K. (2019) Higher Education Challenges for Migrants and Refugee Students in a Global World. Oxford: Peter Lang Publishing Inc . 
[3] Aristotle. 1926. The 'Art' of Rhetoric [367-322 BC]. Translated by JH Freese.

London: William Heinemann.

[4] Bartolomei, T. (2018). As Comunidades: Memória Viva das Democracias. REVER Revista de Estudos da Religião, 18(3), 9-29. doi: https://doi.org/10.23925/16771222.2018vol18i3a2

[5] Bernacki, M. L., Nokes-Malach, T. J., \& Aleven, V. (2015). Examining self-efficacy during learning: variability and relations to behavior, performance, and learning. Metacognition and Learning, 10(1), 99-117. https://doi.org/10.1007/s11409-0149127-x

[6] Bicocca-Gino, R. M. (2017). Análisis crítico-filosófico de las potencialidades educativas de la enseñanza basada en competencias. Educación y Educadores, 20(2), 267-281. DOI: 10.5294/edu.2017.20.2.6 .

[7] Compagno, G. (2015). A Framework of disciplines for basic skills: an inclusive study. Italian Journal Of Educational Research, 0(13), 273-288.

[8] Dewey's Participatory Educational Democracy. Educational Theory, 66(1), 55-71. https://doi.org/10.1111/edth.12152 . Di Pietro, F. (2013). Aspetti socio-culturali e trasversalità nella certificazione delle competenze. Studium educationis, 3, 61 70. Recuperato da:

http://ojs.pensamultimedia.it/index.php/studium/article/view/471

[9] Efklides, A. (2011). Interactions of Metacognition With Motivation and Affect in Self-Regulated Learning: The MASRL Model. Educational Psychologist, 46(1), 6-25. https://doi.org/10.1080/00461520.2011.538645 .

[10] European Commission (2020) European Qualifications Framework. Available online at: https://ec.europa.eu/ploteus/content/descriptors-page accessed 21st May 2020.

[11] European Council. (2006). Recommendation of the European Parliament and of the Council of 18 December 2006 on key competences for lifelong learning. Available online at: https://eur-lex.europa.eu/legalcontent/EN/TXT/HTML/?uri=CELEX:32006H0962\&from=EN accessed 28th May 2020.

[12] European Policy Cooperation (ET2020) Education and Training available online at: https://ec.europa.eu/education/policies/european-policy-cooperation/et2020framework_en accessed 28th May 2020.

[13] Hall, E. (2015) Gaisford 2015 Lecture: Pearls before Swine? The Past \& Future of Greek. Oxford: Oxford University. Horizon 2020 (2020) Science With and For Society. https://ec.europa.eu/programmes/horizon2020/en/h2020section/science-and-society .

[14] Jucks, R., \& Paus, E. (2012). What makes a word difficult? Insights into the mental representation of technical terms. Metacognition and Learning, 7(2), 91-111. https://doi.org/10.1007/s11409-011-9084-6

[15] Kant, I. (1785) Groundwork of the metaphysics of morals. London: Harper Collins.

[16] MUR (2007) Italian Decree No. 139 (2007). Decreto ministeriale n. 139 del 22 agosto 2007. Regolamento recante norme in materia di adempimento dell'obbligo di istruzione, ai sensi dell'articolo 1, comma 622, della legge 27 dicembre 2006, n. 296. Gazzetta Ufficiale Serie Generale n.202 del 31-08-2007. Available online at: https://www.gazzettaufficiale.it/eli/id/2007/08/31/007G0154/sg accessed 28th May 2020. 
[17] Pring, R. (2016). My philosophy of education and how it might relate to classical subjects. The Journal of Classics Teaching 17 (33), 1-5. https://doi.org/10.1017/S2058631016000039

[18] Riva, M. G. (2017). Riflessioni clinico-pedagogiche sulle soft skills nei percorsi formativi per le professioni educative. Pedagogia Oggi, 15(2). Recuperato da http://ojs.pensamultimedia.it/index.php/siped/article/ view/2400

[19] Rossi, L.E., \& Nicolai, R. (2015). Letteratura Greca: storia, luoghi, occasioni. L'età arcaica (vol. 1). Milano: Le Monnier Scuola.

[20] Ruşitoru, M., Taysum, A., Kallioniemi, A. (2020) Towards new management and governance of lifelong learning policies in the XXI ${ }^{\text {st }}$ century in Swiss Journal of Educational Research.

[21] Saran, R. and Neisser, B. (2004). Enquiring Minds. London: Trentham Books Ltd.

[22] Taysum, A., Arar, K., Chopra, P., Imam, H., Harrison, K., McNamara, G., O’Hara, J., Pogosian, V., Mynbayeva, A., Yelbayeva, Z., McGuinness, S., and Collins Ayanlaja, C. (2020) Optimising Well-Being and Learning Through Participatory Processes and Practices: an International Comparative Analysis of Ten Groundwork Case-Studies in Schools in Italian Journal of Sociology of Education, 12, (1) 182-210.

[23] Taysum, A. (2019) An Innovative strategy to re-build trust in educational governance systems after 40 years of English destabilising rapid reforms in Journal of Education Administration and History DOI: 10.1080/00220620.2019.1605341. Taysum, A. (2019) Education Policy as a Road Map to Achieving the Sustainable Development Goal. Scarborough: Emerald.

[24] Arar, K. and Taysum, A. (2019) From hierarchical leadership to a mark of distributed leadership by whole school inquiry in partnership with Higher Education Institutions: comparing the Arab education in Israel with the education system in England in International Journal of Leadership in Education.

[25] Taysum, A. and Arar, K. (2018). Turbulence, Empowerment and Marginalised Groups in International Education Governance Systems. Scarborough Emerald.

[26] Taysum, A. (2017) 'Systems Theory and education: A philosophical enquiry into Education Systems Theory' In P. Higgs, and Y. Waghid (eds) A Reader for Philosophy of Education.

[27] Taysum, A. (2012). Evidence informed leadership in Education. London: Bloomsbury.

[28] Taysum, A. and Iqbal, M. (2012) "What counts as meaningful and worthwhile policy analysis" Italian Journal of Sociology of Education". 4 (1) pp. 11- 28.

[29] United Nations (2016) Sustainable Development Goals. Available at https://sustainabledevelopment.un.org/post2015/transformingourworld downloaded 6th May 2019.

[30] Vidal Ledo, M., Salas Perea, R., Fernández Oliva, B., \& García Meriño, A. (2016). Educación basada en competencias. Educación Médica Superior, 30(1), 0-0. Retrieved from http://www.ems.sld.cu/index.php/ems/article/view/801/335 Visnovsky, E., \& Zolcer, S. (2016). 